\title{
Comparison of the Histological Response to Different Bulking Materials Used in Endoscopic Vesicoureteral Reflux Surgery
}

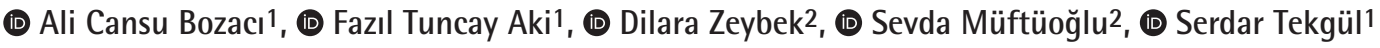 \\ ${ }^{1}$ Hacettepe University Faculty of Medicine, Department of Urology, Ankara, Turkiye \\ 2Hacettepe University Faculty of Medicine, Department of Histology and Embryology, Ankara, Turkiye
}

\section{What's known on the subject? and What does the study add?}

Subureteral injection of various bulking agents became the preferred treatment modality of vesicoureteral reflux. The ideal bulking agent should have a good mound effect at the tissue and preserve this effect for long term without any tissue reaction. This study aimed to compare the histologic effects of three bulking agents used in this era. We found that materials containing dextranomere hyaluronic acid can form satisfying degree of mound effect with adequate capsule duration as polyacrilate polyalcohol copolymer/glycerol materials without significantly less chronic inflammation around injection area. This information can help the clinician to make decision on material choosing during, especially about the possible further ureter obstruction after injection, and further secondary open surgery difficulties.

\section{Abstract}

Objective: To compare the histological responses of 3 bulking agents, which are used in the endoscopic treatment of vesicoureteral reflux, on rats' urinary bladder and subcutaneous tissue.

Materials and Methods: Thirty rats were divided into 3 groups according to the injection materials; Dextranomer Hyaluronic acid- Deflux ${ }^{\circledR}$ (DxHADf), Dextranomer Hyaluronic acid- Deal ${ }^{\circledR}$ (DxHA-Dx) and Polyacrilate Polialcohol Copolymer-Vantris ${ }^{\circledR}$ (PPC). In each group, material was injected both into the submucosa of the rats' urinary bladder dome and the subcutaneous tissue at their names. In each group, 5 rats were scarified at the $2^{\text {nd }}$ and $6^{\text {th }}$ months after injection. The histopathologic compartment was performed by scoring inflammation, neutrophil, eosinophil, macrophage, mast cell and giant cell reactions around the injected material.

Results: All materials maintained their bulky effect. Despite the large amount of degradation with dextranomer materials, there was minimal degradation with PPC. The materials had the same amount of capsule formation around the injection site, which was not related to the degradation properties of the material. There was no statistically significant result for bladder injections. For subcutaneous injections mast cell scores around the injection (DxHA-Df, DxHA-Dx, PPC: 1.4, 1.2, 0 respectively, $\mathrm{p}=0.024)$ were significantly different at $2^{\text {nd }}$ month. Mast cell scores around the injection (DxHA-Df, DxHA-Dx, PPC: 1.0, 1.75, 0 respectively, $\mathrm{p}=0.007$ ) were significantly different at $6^{\text {th }}$ month also. The inflammation around PPC was higher at the 6th month (DxHA-Df, DxHA-Dx, PPC: 1, 1, 3.5 respectively, $\mathrm{p}<0.05)$.

Conclusion: Both dextranomer agents were degradable with good capsule formation and minimal inflammation in the adjacent tissue. PPC degraded minimally and caused significant inflammation at adjacent tissue.

Keywords: Vesicoureteral reflux, endoscopic treatment, injection materials

Correspondence: Ali Cansu Bozacı MD, Hacettepe University Faculty of Medicine, Department of Urology, Ankara, Turkiye Phone: +90 5332320302 E-mail: alicansu@doctor.com ORCID-ID: orcid.org/0000-0001-8726-8509 


\section{Introduction}

In the last two decades, subureteral injection of various bulking agents has become the preferred treatment modality of vesicoureteral reflux (VUR). This relatively easy, safe and efficient method increases the intravesical length of ureters, narrows the ureter lumen, and fixes the lower end of the ureter in the bladder wall by local fibrosis. The ideal bulking agent should have a good mound effect at the tissue and preserve this effect for a long term without any tissue reaction. The injection should be easy to apply and the material must be stable at its injection area without local or distant migration. The durability of the bulking agent and local tissue reaction are key elements, which also have significant impacts on the success of treatment.

The success of the endoscopic technique depends on many different factors such the reflux grade $(1,2)$, voiding dysfunction (3), operator (2), and physicochemical properties of the injected material (4). Therefore, clinic studies do not seem suitable in terms of comparing only the injection materials' role in success. The purpose of this animal model is to compare the histological responses of 3 injection materials (2 different dextranomer materials, 1 polyacrylate material) on rat bladder and subcutaneous tissue and interpret the results with possible clinical situations.

\section{Materials and Methods}

\section{Animals}

The Institutional Care and Use Committee approved (Hacettepe University Animal Experimentations Local Ethics Board 2010/25-3) the study design, and researchers were accredited by Guidelines of Responsible Use and Human care. A total of 30 healthy male adult Sprague-Dawley rats grown to mean 352 grams (328-424 gr) and maintained at Hacettepe University Faculty of Medicine Experimental Animal Laboratory in temperature-controlled cages and a dark-light circle with free access to water and food.

\section{Procedure}

All injections and surgical interventions were performed out with sterile technique under general anesthesia with intraperitoneal xylazin $5 \mathrm{mg} / \mathrm{kg}$ and ketamine $15 \mathrm{mg} / \mathrm{kg}$. Thirty rats were grouped into 3 for each material and sacrificed with carbon monoxide at $2^{\text {nd }}$ and $6^{\text {th }}$ months after the injections.

The three injection materials commercially available were compared in this study:

1. Dexell ${ }^{\oplus}$ (istem Medikal, Ankara, Turkey (DxHA-Dx): Dextranomer microspheres $50 \mathrm{mg} \backslash 1 \mathrm{cc}$, Hyaluronic acid $17 \mathrm{mg} \backslash 1$ cc, Sodium chloride $6.9 \mathrm{mg} / 1 \mathrm{cc}$
2. Deflux (Q-Med AB, Uppsala, Sweden) (DxHA-Df): Dextranomer microspheres $50 \mathrm{mg} \backslash 1 \mathrm{cc}$, Hyaluronic acid $15 \mathrm{mg} \backslash 1$ cc, Sodium chloride $6.9 \mathrm{mg} / 1 \mathrm{cc}$

3. Vantris ${ }^{\odot}$ (Promedon, Cordoba, Argentina) (PPC): Polyacrylate polyalcohol copolymer $60 \%$, glycerol $40 \%$.

The same researcher (A.C.B) performed all injections. PPD needles were adapted to commercial injectors containing study materials and scaled by $0.1 \mathrm{cc}$. The hair on the nape and abdomen was shaved. 0.1 cc of material was injected subcutaneously into the midline of the napes of the animals. Afterwards, bladder was exposed through $2 \mathrm{~cm}$ long vertical suprapubic incisions and emptied with palpation. Bladders were held with atraumatic forceps and traction was performed from the lateral walls. 0.1 cc of study material was injected into bladder wall at the dome. The abdomens were sutured and closed.

\section{Outcomes}

The experiments were terminated at $2^{\text {nd }}$ and $6^{\text {th }}$ month. After scarification, injection sites in the names were excised with 0.5 $\mathrm{cm}$ lateral margin. Abdomens were re-explored through the previous incision site, and bladders were removed by excising through the bladder neck. Excised tissues were kept in 10\% formalin solution and prepared for inspection under a light microscope. $5 \mu \mathrm{m}$ thick slides were stained with HematoxylinEosin and Masson's trichrome.

Two histologists who were blinded to the groups examined and photographed the slides. Capsule thickness was measured using Leica Application Suite Programme ${ }^{\circ}$. Neutrophils, eosinophils, macrophages, mast cells, and giant cells around the injected material were counted and scored as described by Raut et al. (5) (Table 1).

\section{Statistical Analysis}

Statistical analyses were performed using SPSS 15.0 Program $^{\circ}$ and $p<0.05$ was considered as significant. Subgroups (classified according to time of sacrifice) were compared with KruskalWallis tests. Conover's two-sample squared rank test for equality of variance was used to determine the subgroup leading to the difference.

Table 1. Scoring of inflammatory cells according to Raut et al scoring system (5). (Counted in 1 microscopic field under $\mathrm{x} 40$ magnification)

\begin{tabular}{|l|l|}
\hline Score & Number of cells counted \\
\hline 0 & None \\
\hline 1 & $1-5$ cells \\
\hline 2 & $6-15$ cells \\
\hline 3 & $16-25$ cells \\
\hline 4 & $\geq 26$ cells \\
\hline
\end{tabular}




\section{Results}

\section{a. Histological Findings in Bladder Sections}

During scarification, in some urinary bladders, there were no injection materials at the site of injection. Also, in their histological sections, no injection materials were seen. That is most probably the result of the thin bladder wall of rats and the leakage of material into the lumen or peritoneum after injection, which was an expected result after our pilot study. That is why we planned also to have injections into the subcutaneous tissue. The missing data was distributed equally into the groups and this error did not affect our statistical compartments. In specimens harboring the materials, biomaterials were concentrated within the lamina propria between the epithelial and muscular layers of the urinary bladder, which caused flattening of the overlying epithelium and protrusion into the lumen slightly. Microspheres could both be seen with full of material or empty at the injection area of each material. Capillaries and cellular infiltration, including active fibroblasts and infiltrative cells (especially lymphocytes) and rare multicellular giant cells, were observed within and around the microsphere groups (Figure 1). Lymphocytes and occasional mast cells were present outside the capsule, which was made of collagen fibrils and fibroblasts starting from the $2^{\text {nd }}$ month groups. Degraded empty microspheres could have seen in $2^{\text {nd }}$ and $6^{\text {th }}$ month groups for each biomaterial.

Degradation of DxHA-DX and DxHA-DF was observed to get started earlier and to be completed at $6^{\text {th }}$ month sections. However, the degradation of PPC was minimal with persisting full microspheres in $6^{\text {th }}$ month sections.

For an objective comparison, infiltration and inflammatory cells were scored, and mean capsule thicknesses were calculated for each group (Table 2 and 3 ).

Both in $2^{\text {nd }}$ and $6^{\text {th }}$ month sections, all three groups were similar for all parameters (Table 3). Observationally, capsular and intracapsular collagen fibers were thicker, giant cell response was weaker and lymphocytic infiltration around the capsule was prominent in the PPC group, however there were no statistical differences among the groups (Table 2 and 3).

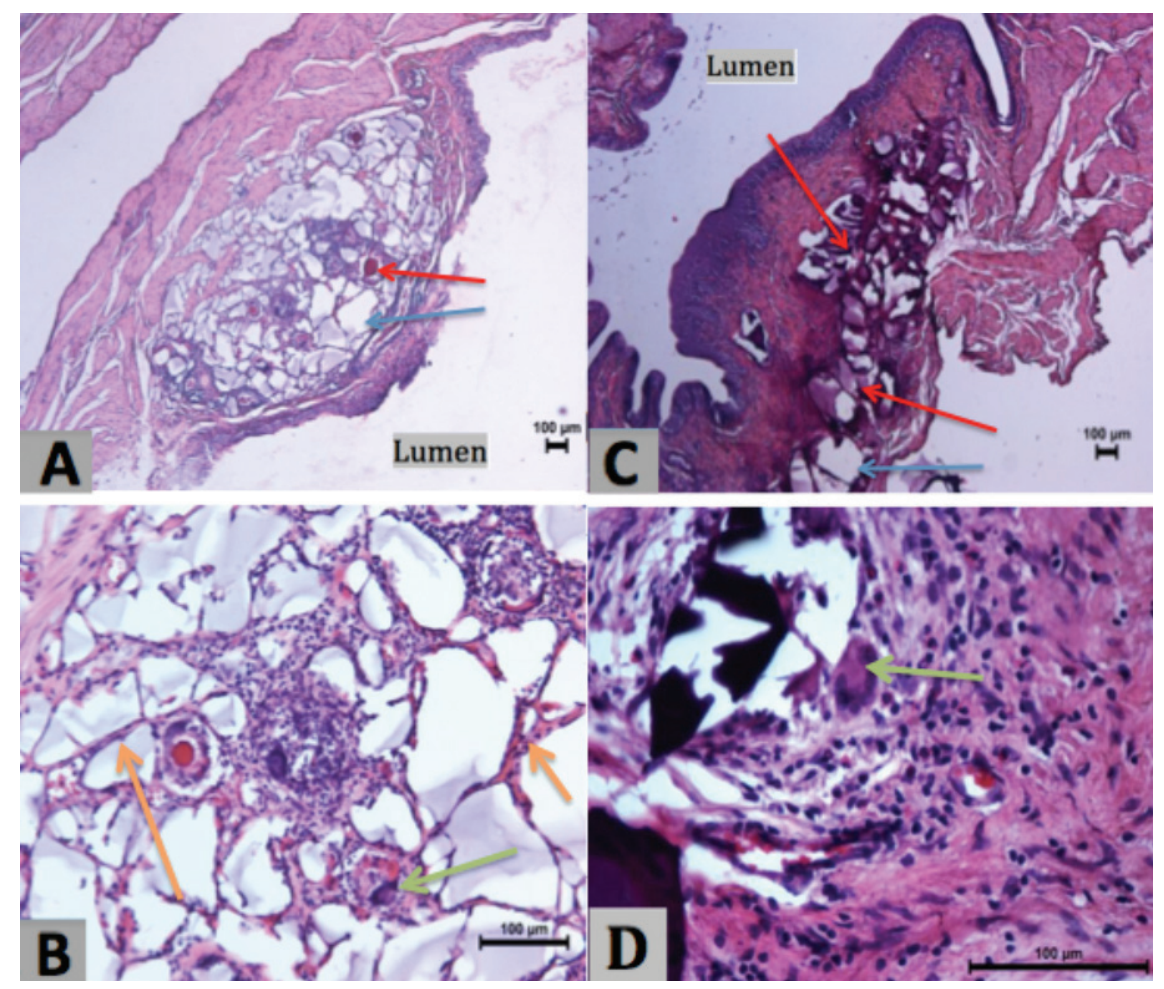

Figure 1. Bladder sections at $6^{\text {th }}$ month. A. DxHA-Df (Deflux) injection site. Most of the microsphers are degraded (blue arrow), unique full microsphers are still exist rarely (red arrow). Bulking effect is seen, flattering of overlying epithelium and protrusion into the lumen slightly. (Hemotoxylin \& eosin staining, $x 25)$. C. PPC (Vantris) injection site. Most of the microsphers are not degraded (red arrows), unique degraded microsphers are seen (blue arrow). Bulking effect is seen, flattering of overlying epithelium and protrusion into the lumen slightly. (Hemotoxylin \& eosin staining, x25). B. Inside of the DxHA-Df (Deflux) injection site. Capillaries and cellular infiltration including active fibroblasts (orange arrows) and infiltrative cells (especially lymphocytes) and rare multicellular giant cells (green arrow) were observed within and around the microsphere groups (Hemotoxylin \& eosin staining, x100). D. Inside of the PPC (Vantris) injection site. Capillaries and cellular infiltration including active fibroblasts and infiltrative cells (especially lymphocytes) and rare multicellular giant cells (green arrow) were observed within and around the microsphere groups (Hemotoxylin \& eosin staining, x100)

PPC: Polyacrilate Polialcohol Copolymer-Vantris, DxHA-Df: Dextranomer Hyaluronic acid- Deflux ${ }^{\circledR}$ 


\section{b. Histological Findings in Subcutaneous Tissues}

Majority of $2^{\text {nd }}$ and $6^{\text {th }}$ month sections in DxHA-DX and DxHADF groups showed complete degradation, whereas degradation was minimal in the PPC group (Figure 2).

Although collagen fibers between and around the PPC microspheres seemed thicker, mean capsule thicknesses of the three groups were found to be statistically similar (Table 2).

Mast cell infiltration around the capsule was higher in DxHA materials $\left(p=0.024\right.$ in $2^{\text {nd }}$ month and $p=0.007$ in $6^{\text {th }}$ month sections). Overall, inflammatory infiltration around the injection site was prominent in $6^{\text {th }}$ month sections of the PPC group $(p<0.05)$. The rest of the histological parameters were statistically the same (Table 3 ).

\begin{tabular}{|c|c|c|c|}
\hline & & $2^{\text {nd }}$ month & $6^{\text {th }}$ month \\
\hline \multirow{3}{*}{$\begin{array}{l}\text { Urinary } \\
\text { bladder }\end{array}$} & $\begin{array}{l}\text { DxHA-DX } \\
(n=2 / 3)\end{array}$ & $\begin{array}{l}73.70 \\
(69.20-78.20)\end{array}$ & $\begin{array}{l}66.77 \\
(64.34-69.20)\end{array}$ \\
\hline & $\begin{array}{l}\text { DxHA-DF } \\
(n=3 / 5)\end{array}$ & $\begin{array}{l}69.62 \\
(65.48-73.76)\end{array}$ & $\begin{array}{l}73.22 \\
(68.94-77.33)\end{array}$ \\
\hline & $\operatorname{PPC}(n=3 / 5)$ & $\begin{array}{l}68.59 \\
(66.28-70.90)\end{array}$ & $\begin{array}{l}73.20 \\
(68.91-75.83)\end{array}$ \\
\hline \multirow{3}{*}{$\begin{array}{l}\text { Subcutaneos } \\
\text { tissue }\end{array}$} & $\begin{array}{l}\text { DxHA-DX } \\
(n=5 / 4)\end{array}$ & $\begin{array}{l}77.78 \\
(73.60-85.80)\end{array}$ & $\begin{array}{l}99.23 \\
(95.70-102.47)\end{array}$ \\
\hline & $\begin{array}{l}\text { DxHA-DF } \\
(n=5 / 4)\end{array}$ & $\begin{array}{l}85.57 \\
(79.59-89.02)\end{array}$ & $\begin{array}{l}89.22 \\
(86.47-107.81)\end{array}$ \\
\hline & $\begin{array}{l}P P C \\
(n=3 / 4)\end{array}$ & $\begin{array}{l}84.11 \\
(80.70-84.52)\end{array}$ & $\begin{array}{l}114.58 \\
(88.64-131.10)\end{array}$ \\
\hline
\end{tabular}

\section{Discussion}

The majority of the materials used in endoscopic treatment of VUR were abandoned either due to their migration to distant tissues, rapid loss of mass effect, or granuloma formation $(4,6)$. DxHA-Df is a biodegradable material containing cross-linked 80-120 $\mu \mathrm{m}$ dextranomer microspheres in a stabilized sodium hyaluronic acid carrier medium gel. The gel is absorbed the following injection, and microspheres induce a rapid fibroblast migration and collagen synthesis leading to the capsule formation. While high success rates for short-medium term ranging between 68 and 92\% were reported (4,7-9); longterm recurrence rates necessitate to research on new materials. DxHA-DX is another biodegradable dextranomer gel with similar physical and chemical properties. PPC is a non-bio-degradable synthetic material as $320 \mu \mathrm{m}$ microspheres in glycerol solution. Due to its large molecular size, its distant migration is unlikely, and the mass effect seems persistent for long term (10).

Microsphere sizes and counts were similar throughout the study period in both tissues and all groups. Degradation of DxHA-DX and DxHA-DF began and were completed earlier than PPC, as expected due to the synthetic non-biodegradable nature of the PPC molecule.

Ideally, the capsule formation should start early and persist for a long time. Dx-HA materials triggered capsule formation around $2^{\text {nd }}$ month and persisted at the $6^{\text {th }}$ month sections independent of degradation. PPC group, capsule formation and thickness were similar to other groups in $2^{\text {nd }}$ and $6^{\text {th }}$ month sections. Also, the capsule formation in the urinary bladder and

\begin{tabular}{|c|c|c|c|c|c|c|c|c|c|}
\hline \multirow{2}{*}{\multicolumn{2}{|c|}{ Infiltration }} & \multicolumn{4}{|c|}{ Urinary Bladder } & \multicolumn{4}{|c|}{ Subcutaneous Tissue } \\
\hline & & 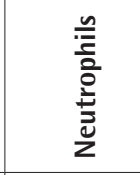 & 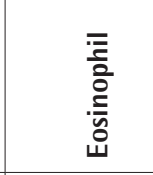 & 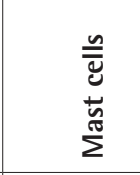 & 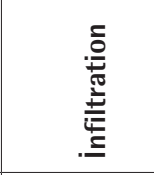 & 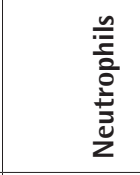 & $\begin{array}{l}\overline{\bar{z}} \\
\overline{\bar{o}} \\
\text { s. } \\
\text { w }\end{array}$ & 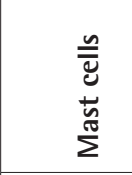 & \\
\hline \multirow{3}{*}{ 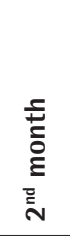 } & DxHA-DX $(n=2 / 5)$ & $0.5(0-1)$ & 0 & $0.5(0-1)$ & $0.5(0-1)$ & $1.6(1-3)$ & 0 & $0.2(1)$ & $1.2(1-2)^{*}$ \\
\hline & DxHA-DF $(n=3 / 5)$ & $1.3(1-4)$ & 0 & $1(0-2)$ & $1(0-2)$ & $3(3)$ & 0 & $0.6(0-1)$ & $1.4(1-2)^{*}$ \\
\hline & $\operatorname{PPC}(n=3 / 3)$ & $3.3(3-4)$ & $0.33(0-1)$ & 0 & $0.33(0-1)$ & $3(1-4)$ & 0 & 0 & $0^{*}$ \\
\hline \multirow{3}{*}{ 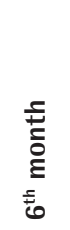 } & DxHA-DX $(n=3 / 4)$ & $2(1-4)$ & 0 & 0 & $0.33(0-1)$ & $1(0-3)^{*}$ & 0 & 0 & $1.75(1-2)^{*}$ \\
\hline & DxHA-DF $(n=5 / 4)$ & $1.6(1-2)$ & $0.2(0-1)$ & $0.6(0-1)$ & $1(0-3)$ & $1(0-3)^{*}$ & 0 & 0 & $1(1)^{*}$ \\
\hline & $\operatorname{PPC}(n=5 / 4)$ & $2(1-4)$ & 0 & $1(0-2)$ & $0.6(0-1)$ & $3.5(3-4)^{*}$ & 0 & 0 & $0^{*}$ \\
\hline
\end{tabular}


subcutaneous tissue sections was similar in all groups (Table 2). Therefore, we can state that the quality and persistence of capsule seems unrelated to degradability of the materials and the tissue properties (Figure 3). Ormaechea et al. (10) reported fibrous capsule thickness reaching $70 \mu \mathrm{m}$ around non-degraded PPC without significant inflammatory or pathologic infiltration 1 year after injection in dog ureters. Researchers attributed the low long-term recurrence rate after VUR treatment with PPC to non-biodegradable nature of the material in their clinical study (11). However, we think that such a conclusion can only be possible with prospective randomized trials on many control groups in which other (both biodegradable and non- biodegradable) biomaterials are also used, and clinical success rates or histological features are compared in longer time intervals. Unfortunately, in this study we do not have long-term (1 year or longer) data. Contrary to the findings of Ormaechea et al. (10), we saw prominent inflammation around PPC in $6^{\text {th }}$ month sections (Table 3 ).

Although some giant cells could be seen inside the materials, we did not see any granuloma formation both inside and outside all material injections except one rat's bladder in the DxHA-Dx group. As Stenberg et al. (12) mention in their study, giant cells are expected within dextranomer injection
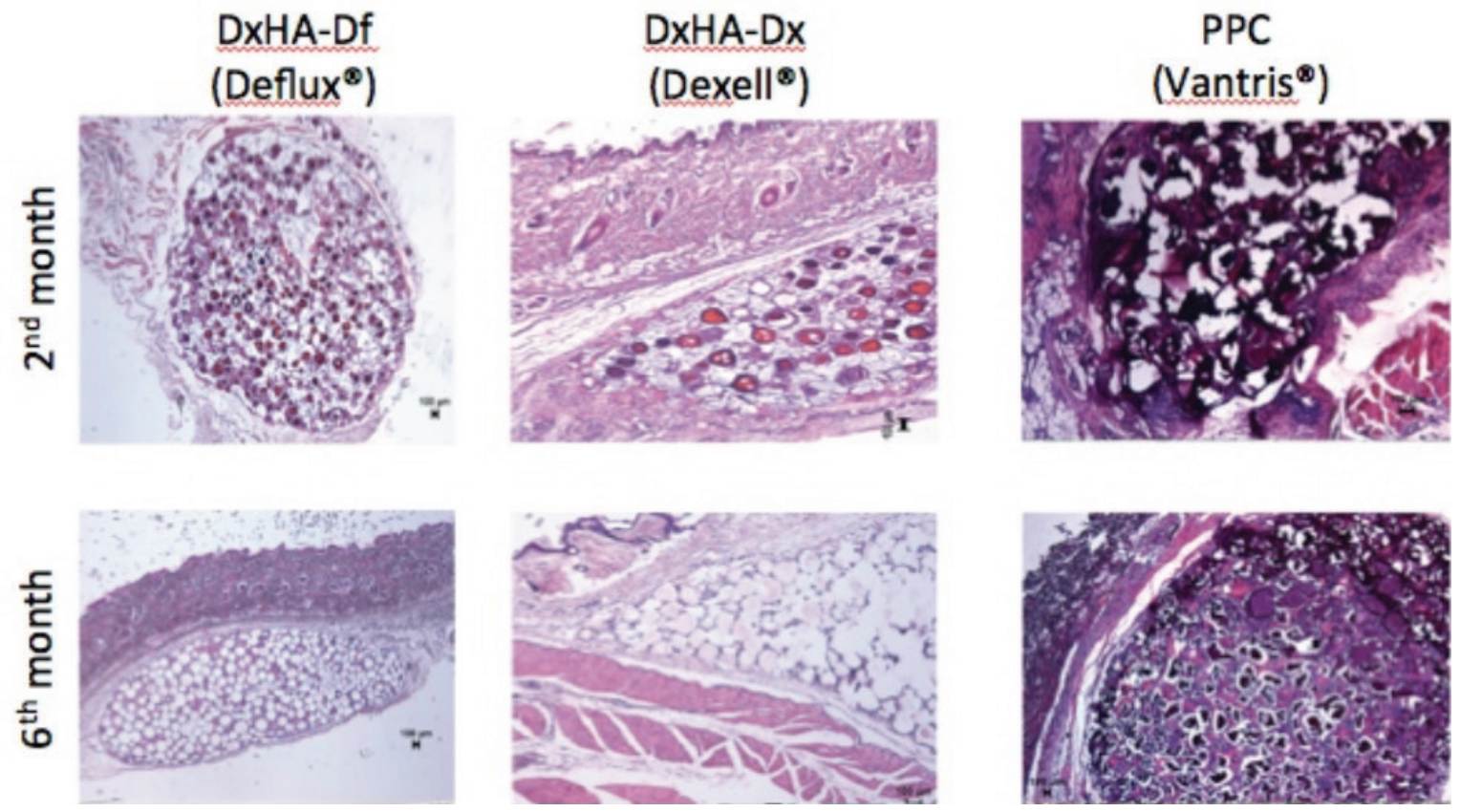

Figure 2. Amount of degradation in subcutaneous tissue of different materials at $2^{\text {nd }}$ and $6^{\text {th }}$ months. For DxHA materials degradation starts early and nearly completes in $6^{\text {th }}$ month. But most of the injection material stays in PPC at $6^{\text {th }}$ month. (Hematoxylin $\&$ Eosin, $x 25$ magnification at light microscope, scale at the bottom: $100 \mu \mathrm{m})$

PPC: Polyacrilate Polialcohol Copolymer-Vantris, DxHA: Dextranomer Hyaluronic acid
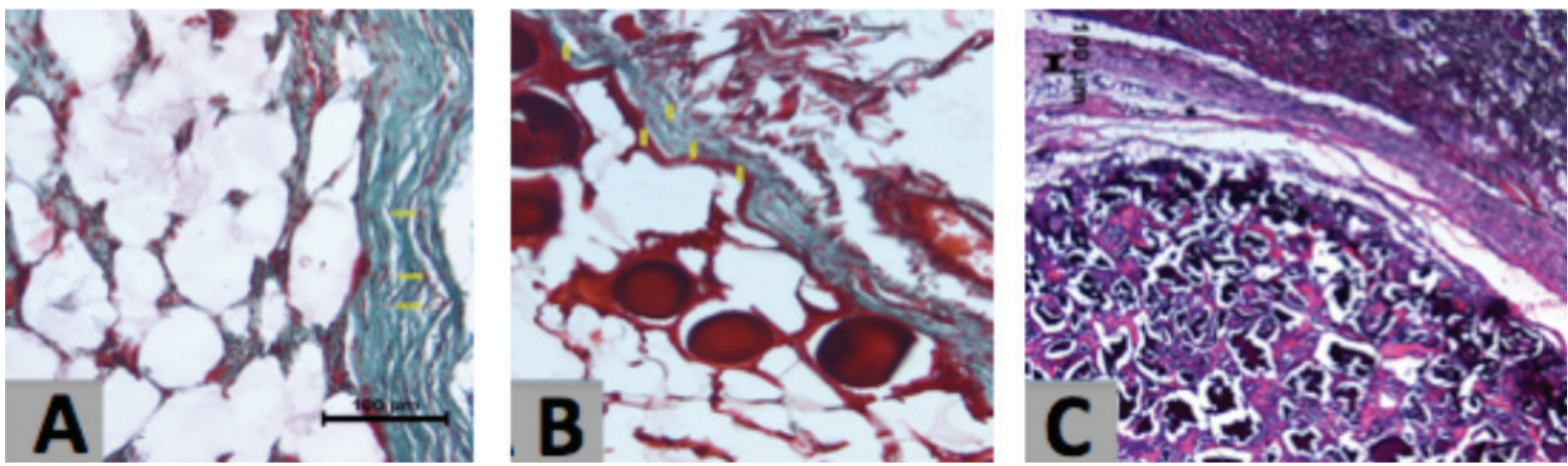

Figure 3. Capsule formations. ( $6^{\text {th }}$ month, subcutanous tissue). All three materials have statistically equal amount of capsule formation. A. DxHA-Dx (Masson's trichrome x200), B. DxHA-Df (Masson's trichrome x200), C. PPC (Hematoxylene-Eosin x25)

PPC: Polyacrilate Polialcohol Copolymer-Vantris, DxHA-Df: Dextranomer Hyaluronic acid- Deflux ${ }^{\circledR}$, DxHA-Dx: Dextranomer Hyaluronic acid- Deal ${ }^{\circledR}$ 
area with collagen fibers as a result of the natural remodeling process. Giant cell reaction in the injection site is replaced by fibrosis and connective tissue formation during degradation progress. Mononuclear cell migration, mostly lymphocytes, was infiltrated full microspheres in early sections. As degradation proceeded, this infiltration was replaced by fibroblasts to start collagen formation and form a honeycomb appearance of empty microspheres. Previously, Broderick et al. (7) attributed failure of endoscopic VUR treatment in a 6-year-old child to phagocytosis of the injected material by giant cells shown in histological sections of distal ureters 5 months after the operation. Also, Alkan et al. (13) reported granuloma formation in $43.3 \%$ of the animals. However, we found a granuloma formation in only one histological section, which was obtained from the urinary bladder of one animal from the DxHA-Dx group. Therefore, we think that this pathological aggravation of the giant cell reaction is not a common feature and probably depends on host-specific factors rather than material properties.

Mast cell scores were higher for DxHA groups significantly for both $2^{\text {nd }}$ and $6^{\text {th }}$ months in subcutaneous tissue specimens (Table 3). As is known, tryptase secretion of these mast cells promotes the conversion of fibroblasts to myofibroblasts, which synthesis matrix elements of new connective tissue (14). It was just a slight difference in terms of cell number, which is not pathologic in a normal tissue reaction. Also, eosinophilic infiltration is nearly absent in specimens obtained from all groups in all periods. So, both findings suggest that mast cells are elements of a normal inflammatory process rather than an immunologic/allergic reaction, and biomaterials are similar in terms of allergic/immunogenic potential.

Kajbafzadeh et al. (15) compared the short- and long-term (1 $1^{\text {st }}$ and $6^{\text {th }}$ months) local tissue reactions against PPC and DxHA-Df in bladders of eight rabbits. Inflammation markers (leucocyte common antibody and CD68) were significantly higher in the PPC group, both for short- and long-term specimens. While mild fibrosis of the DxHA-Df group in the short term subsided to non-noticeable levels in the long-term; severe fibrosis of the PPC group in the $1^{\text {st }}$ month only decreased to a moderate level in $6^{\text {th }}$ month. Our results overlap with this recent study. Also, we establish that a significantly persistent chronic inflammatory reaction continues around PPC material. This finding may indicate out continuous foreign body reaction and inflammation around non-biodegradable material, which may increase periureteral fibrosis causing an ureteral obstruction.

As we reviewed the literature, common conclusion of authors is to have a long term follow up endoscopically treated reflux patients, to detect reflux failure and upper urinary tract obstructions, for all kinds of injection materials. Data about the patients who needed urinary diversions (JJ stents/percutaneous nephrostomies) and open surgical repairs have been reported in many endoscopic treatment series (16-19). Although it is not objective to compare the role of the injection material in obstruction with these published papers, it can be realized that PPC has a higher potential risk of obstruction with less amount of material (20). These histological responses we detected might be a part of the puzzle for the explanation of the relatively higher postoperative obstruction (1.2-6.6\%) reported in the PPC series $(14,21,22)$. After our rat study, we believe that the sustaining inflammation around the PPC injection site can be a possible cause of obstructions. For an objective conclusion, we need long-term clinical results of case series, and meta-analysis to compare the results/complications of different materials.

\section{Study Limitations}

The small size of animals' urinary bladders led to difficulties in obtaining a standard injection volume and exact determination of material volumes. That's why we also injected all materials into the subcutaneous tissue of the napes of animals, to reach the nearly same injection volume for an objective outcome. Flattering the overlying bladder epithelium at the injection site is annotated as the maintenance of the mass effect.

Like other animal studies, this study also is far from making certain conclusions about the long-term results as maintaining bulking effect, the inflammation state, malignancy/immunologic complications. Long-term results of clinical case series, and meta-analysis comparing the results/complications of different materials can help us have more objective conclusions.

\section{Conclusion}

All used biomaterials in this study formed adequate capsule formation and maintained mass effect throughout the study period without toxic, immunologic, or neoplastic reactions. DxHA was seen to be degraded almost completely, whereas PPC was degraded only minimally at the end of the study. However, this finding cannot guarantee long-term effectiveness of PPC and randomized controlled studies conducted in longer periods on larger samples are needed. Long lasting and prominent inflammation around PPC may result in periureteral fibrosis and lack of pliability resulting in ureteral obstructions. Histological evaluations of the lower ends of ureters in cases that undergo ureteroneocystostomy after failed endoscopic treatments provide invaluable data.

\section{Ethics}

Ethics Committee Approval: The Institutional Care and Use Committee approved (Hacettepe University Animal Experimentations Local Ethics Board 2010/25-3) the study design, and researchers were accredited by Guidelines of Responsible Use and Human care. 


\section{Informed Consent: Not necessary.}

Peer-review: Externally and internally peer-reviewed.

\section{Authorship Contributions}

Surgical and Medical Practices: A.C.B., F.T.A., D.Z., S.M., Concept: A.C.B., F.T.A., D.Z., S.T., Design: A.C.B., F.T.A., D.Z., S.M., S.T., Data Collection or Processing: A.C.B., D.Z., S.M., Analysis or Interpretation: A.C.B., F.T.A., D.Z., Literature Search: A.C.B., F.T.A., D.Z., Writing: A.C.B., F.T.A., D.Z.

Conflict of Interest: No conflict of interest was declared by the authors.

Financial Disclosure: Elit Medical financed this study' expenses. The company played no role in the study design, in the collection, analysis and interpretation of data; in the writing of the manuscript; or in the decision to submit the manuscript for publication.

\section{References}

1. Kajbafzadeh AM, Tourchi A, Aryan Z. Factors that impact the outcome of endoscopic correction of vesicoureteral reflux: a multivariate analysis. Int Urol Nephrol 2013;45:1-9.

2. Routh JC, Reinberg Y. Predicting success in the endoscopic management of pediatric vesicoureteral reflux. Urology 2010;76:195-198.

3. Coletta R, Olivieri C, Briganti V, Perrotta ML, Oriolo L, Fabbri F, Calisti A. Patients with a history of infection and voiding dysfunction are at risk for recurrence after successful endoscopic treatment of vesico ureteral reflux and deserve long-term follow up. Urol Ann 2012;4:19-23.

4. Chertin B, Kocherov S, Chertin L, Natsheh A, Farkas A, Shenfeld OZ, Halachmi S. Endoscopic bulking materials for the treatment of vesicoureteral reflux: a review of our 20 years of experience and review of the literature. Adv Urol 2011;2011:309626.

5. Raut VP, Patterson TE, Wenke JC, Hollinger JO, Muschler GF. Assessment of Biomaterials: Standardized In Vivo Testing. New York: CRC Press, Taylor and Francis Group; 2012.

6. Malizia AA Jr, Reiman HM, Myers RP, Sande JR, Barham SS, Benson RC $J \mathrm{~J}$, Dewanjee MK, Utz WJ. Migration and granulomatous reaction after periurethral injection of polytef (Teflon). JAMA 1984;251:3277-3281.

7. Broderick K, Thompson JH, Khan AR, Greenfield SP. Giant cell reaction with phagocytosis adjacent to dextranomer-hyaluronic acid (Deflux) implant: possible reason for Deflux failure. J Pediatr Urol 2008;4:319-321.

8. Kirsch AJ, Perez-Brayfield M, Smith EA, Scherz HC. The modified sting procedure to correct vesicoureteral reflux: improved results with submucosal implantation within the intramural ureter. J Urol 2004;171(6 Pt 1):2413-2419.

9. Routh JC, Vandersteen DR, Pfefferle H, Wolpert JJ, Reinberg Y. Single center experience with endoscopic management of vesicoureteral reflux in children. J Urol 2006;175:1889-1892; discussion 92-3.
10. Ormaechea $M$, Paladini $M$, Pisano $R$, Scagliotti $M$, Sambuelli $R$, Lopez $S$, Guidi A, Muñoz J, Rossetti V, Carnerero M, Beltramo D, Alasino R, Bianco I, Griguol O, Valladares D, De Badiola F. Vantris, a biocompatible, synthetic, non-biodegradable, easy-to-inject bulking substance. Evaluation of local tissular reaction, localized migration and long-distance migration. Arch Esp Urol 2008;61:263-268.

11. Ormaechea $M$, Ruiz $E$, Denes $E$, Gimenez $F$, Denes $F$, Moldes J, Amarante A, Pioner G, Dekermacher $S$, de Badiola F. New tissue bulking agent (polyacrylate polyalcohol) for treating vesicoureteral reflux: preliminary results in children. J Urol 2010;183:714-717.

12. Stenberg A, Larsson $E$, Lindholm A, Ronneus B, Stenberg A, Lackgren G. Injectable Dextronomer-based implant: Histopatology, volume changes, and DNA-analysis. Scand J Urol Nephrol 1999; 33:355-361.

13. Alkan M, Ciftci AO, Talim B, Senocak ME, Caglar M, Buyukpamukcu N. Histological response to injected dextranomer-based implant in a rat model. Pediatric Surgery International 2007;23:183-187.

14. Arena S, Fazzari C, Implatini A, Torre S, Villari D, Arena F, Benedetto VD. Dextranomer/hyaluronic Acid copolymer implant for vesicoureteral reflux: role of myofibroblast differentiation. J Urol 2009;181:2695-2701.

15. Kajbafzadeh A, Sabtkish S, Khorramirouz R, Sabtkish N. Comparision of histopathological characteristics of polyacrylate polyalcohol copolymer with dextranomer/hyaluronic acid after injection beneath the bladder mucosa layer: a rabbit model. Int Urol Nephrol 2017;49:747-752.

16. Chertin B, Arafeh WA, Zeldin A, Ostrovsky IA, Kocherov S. Endoscopic correction of VUR using vantris as a new non-biodegradable tissue augmenting substance: three years of prospective follow-up. Urology 2013;82:201-204.

17. Akin M, Erginel B, Karadag CA, Yildiz A, Ozçelik GS, Sever N, Genc NM, Dokucu Al. A comparison of the double hydrodistention implantation technique (HIT) and the HIT with a polyacrylate/polyalcohol copolymer (PPC) for the endoscopic treatment of primary vesicoureteral reflux. Int Urol Nephrol 2014;46:2057-2061.

18. Rubenwolf PC1, Ebert AK, Ruemmele P, Rösch WH. Delayed-onset ureteral obstruction after endoscopic dextranomer/hyaluronic acid copolymer (Deflux) injection for treatment of vesicoureteral reflux in children: a case series. Urology 2013;81:659-662.

19. Alizadeh $F$, Mazdak $H$, Khorrami MH, Khalighinejad $P$, Shoureshi $P$. Postoperative ureteral obstruction after endoscopic treatment of vesicoureteral reflux with polyacrylate polyalcohol copolymer (Vantris $\left.{ }^{\circledR}\right)$. J Pediatr Urol 2013:9:488-492.

20. Tekin A, Yagmur I, Tiryaki S, Dokumcu Z, Ulman I, Avanoglu A. Changing bulking agent may require change in injection volume for endoscopic treatment of vesicoureteral reflux. Int Braz J Urol 2018;44:1194-1199.

21. Kocherov S, Ulman I, Nikolaev $S$, Corbetta JP, Rudin $Y$, Slavkovic A Dokumcu Z, Avanoglu A, Menovshchikova L, Kovarskiy S, Skliarova T, Weller S, Bortagaray JI, Lopez JC, Durán V, Burek C, Sager C, Maruhnenko D, Garmanova T, Djamal A, Jovanovic Z, Vacic N, Abu Arafeh W, Chertin B. Multicenter survey of endoscopic treatment of vesicoureteral reflux using polyacrylate-polyalcohol bulking copolymer (Vantris). Urology 2014;84:689-693.

22. Chertin B, Mele E, Kocherov S, Zilber S, Gerocarni Nappo S, Capozza N. What are the predictive factors leading to ureteral obstruction following endoscopic correction of VUR in the pediatric population? Pediatr Urol 2018;14:538.e1-538.e7. 